\title{
Two new species of Diplococcium from the tropics
}

\author{
T. K. Goh ${ }^{1}$ \\ K. D. Hyde \\ T. E. Umali \\ Department of Ecology and Biodiversity, The University \\ of Hong Kong, Pokfulam Road, Hong Kong
}

\begin{abstract}
Two new species of Diplococcium are described and illustrated. Diplococcium aquaticum sp. nov., from submerged wood in Australia, is distinct in the genus in having slender conidiophores and pyriform, uniseptate, bicolored conidia. Diplococcium dendrocalami sp. nov., from senescent culms of Dendrocalamus sp. in the Philippines, differs from other species in the genus in having robust, unbranched, attenuated conidiophores and oblong to ellipsoidal, thick-walled, 1-2-septate, large conidia.
\end{abstract}

Key Words: Hyphomycetes, litter fungi, systematics, taxonomy

The genera Spadicoides S. Hughes and Diplococcium Grove are closely related and have similar conidial ontogeny (Holubová-Jechová, 1982). In both genera, the conidiogenous cells are polytretic (Ellis, 1971b). When conidia detach, pores are clearly visible on the conidiogenous cells where the conidia are borne. Species in both genera produce conidia which are unicellular or have up to 7-eusepta. In many species, the septa are thick and darkly pigmented. The generic concepts of the two genera have been revised by Sinclair et al. (1985), and branching of conidiophores is not considered an important criterion separating them. Catenation of conidia is currently the sole diagnostic character separating Diplococcium from Spadicoides (Goh and Hyde, 1996; Sinclair et al., 1985).

There are presently 30 species described in Diplococcium (Castañeda Ruíz and Kendrick, 1991; Ellis, 1963, 1971a, 1971b, 1976; Holubová-Jechová, 1982; Hughes, 1958; Matsushima, 1993; Pirozynski, 1972; Sinclair et al., 1985; Subramanian and Sekar, 1989; Sutton, 1973; Wang and Sutton, 1982), some of which have been transferred to other genera (Ellis, 1971b, 1976; Hughes, 1958; Sinclair et al., 1985).

Accepted for publication December 5, 1997.

${ }^{1}$ Email: TKGOH@HKUCC.HKU.HK
During our investigation of tropical microfungi, we have collected two Diplococcium species; one on submerged wood in a freshwater lake in north Queensland, Australia, and the other on a senescent bamboo culm in a tropical rain forest in Luzon, Philippines. These two Diplococcium species differ morphologically from other species in the genus and are, therefore, being described as new. Our attempts to grow these two new species in culture were not successful.

Diplococcium aquaticum Goh, K. D. Hyde et Umali, sp. nov.

FIGS. 1-11

Coloniae in substrato naturale effusae, atrobrunneae. Mycelium partim superficiale et partim immersum, ex hyphis ramosis, subhyalinis vel pallide brunneis, laevibus, septatis, 1.5-2 $\mu \mathrm{m}$ latis compositum. Conidiophora ex substratis vel hyphis superficialibus singulatim oriunda, erecta, recta vel leniter flexuosa, sursum interdum nodulata, ad apicem rotundata, septata, ramosa, pallide brunnea vel modice brunnea, ad apicem leniter pallidiora, laevia, 80-180 × 2.5-3 $\mu \mathrm{m}$, in latitudine uniformia. Cellulae conidiogenae in conidiophoris incorporatae, polytreticae, terminales et intercalares. Conidia (5-)7-13 × 4-5 $\mu \mathrm{m}$, breve catenulata, ellipsoidea vel pyriformia, ad apicem late rotundata, laevia, plerumque uniseptata, septum atrum et excentricum ad basem propria, leniter constricta, bicoloria; cellula apicalis atro olivacea vel pallide brunnea, 5-6.5 $\times 4-5 \mu \mathrm{m}$; cellula basalis subhyalina vel pallidissime flavidobrunnea, $2.5-5 \times$ $2.5-4 \mu \mathrm{m}$.

Etymology. aquaticum, referring to the habitat on wood submerged in freshwater.

HOLOTYPE. AUSTRALIA. QUEENSLAND: Atherton Tablelands, Lake Barrine, on submerged wood, 24 Apr. 1996, K. D. Hyde, LB2O (HKU(M) 3201).

Colonies on natural substratum effuse, dark brown. Mycelium partly superficial and partly immersed, composed of branched, subhyaline to pale brown, smooth, septate, 1.5-2 $\mu \mathrm{m}$ wide hyphae. Setae and hyphopodia absent. Conidiophores arising singly directly from the substratum or as lateral branches from the superficial mycelium, erect or ascending, straight or slightly flexuous, apical portion sometimes nodulate, rounded at the tip, septate, branched, pale brown to medium brown, slightly paler at the apex, smooth, 80-180 $\times 2.5-3 \mu \mathrm{m}$, uniform in width. Conidiogenous cells integrated, polytretic, terminal and intercalary. Conidia (5-)7-13 $\times 4-5 \mu \mathrm{m}$, borne in 

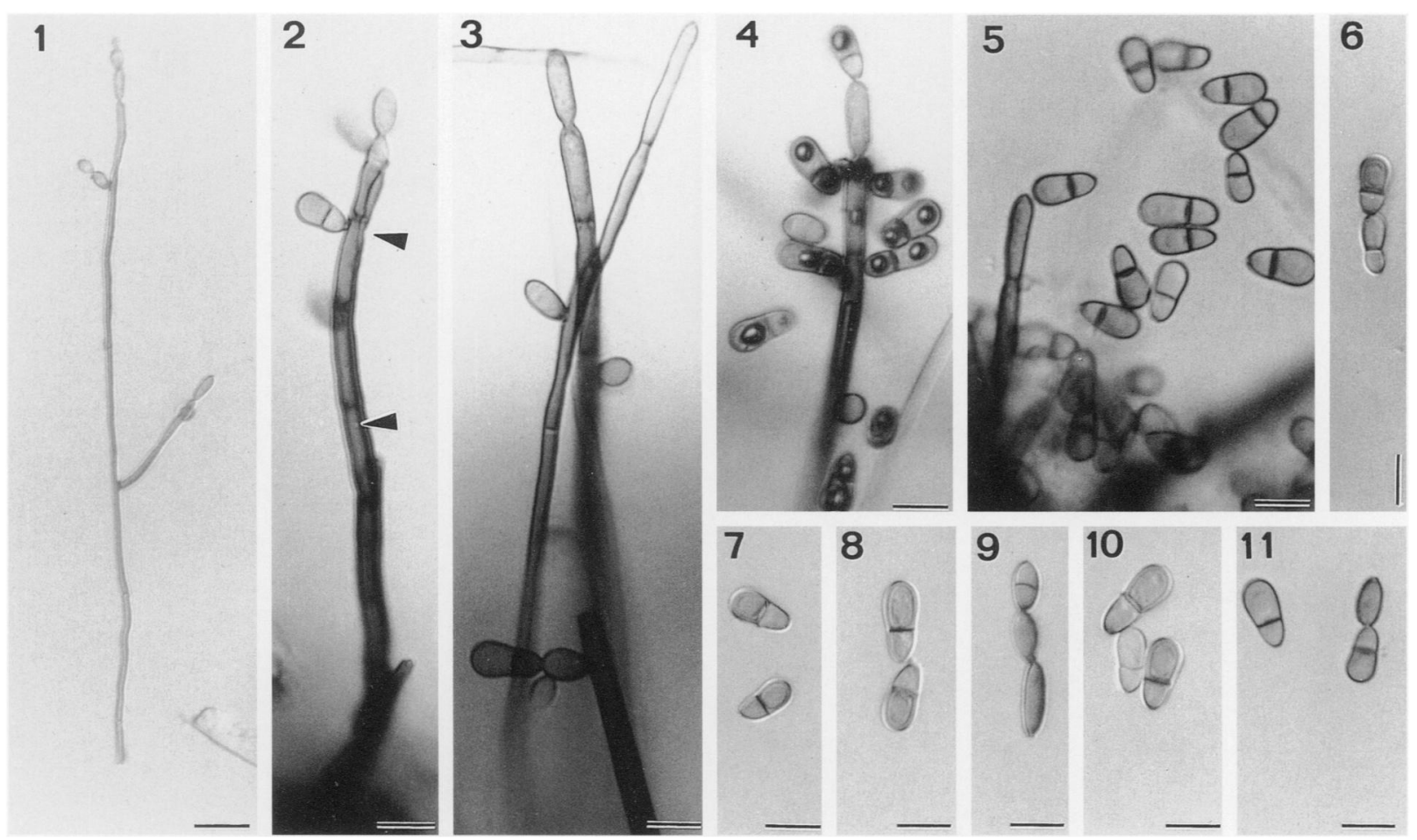

FIGS. 1-11. Diplococcium aquaticum (from HOLOTYPE). 1. A branched conidiophore bearing developing conidia. 2-4. Close-up of apical portion of conidiophores with developing conidia. Note conidiogenous pores (arrowed) in 2. 5-11. Conidia. Scale bars: $1=20 \mu \mathrm{m} ; 2-11=10 \mu \mathrm{m}$.

short chains, ellipsoidal to pyriform, broadly rounded at the apex, smooth, predominantly 1-septate, septum dark and eccentric (closer to the base), slightly constricted at the septum, bicolored; apical cell dark olivaceous to pale brown, 5-6.5 $\times$ 4-5 $\mu \mathrm{m}$; basal cell subhyaline to very pale yellowish brown, $2.5-5 \times 2.5-$ $4 \mu \mathrm{m}$.

Teleomorph. Unknown.

This species is unique in the genus in having slender conidiophores (2.5-3 $\mu \mathrm{m}$ wide) and pyriform conidia. It is comparable to $D$. graminearum $R$. F. Castañeda \& W. B. Kendr. (Castañeda Ruíz and Kendrick, 1991) which also produces uniseptate, bicolored conidia. The latter, however, differs in its unbranched conidiophores and obpyriform conidia, with a central septum. In D. graminearum, the basal cell of the conidia is darker than the apical cell.

Diplococcium dendrocalami Goh, K. D. Hyde et
Umali, sp. nov.

Coloniae in substrato naturale effusae, atro-brunneae. Mycelium immersum. Conidiophora solitaria vel 2-4 gregaria, non ramosa, erecta, recta, attenuata, 120-280 $\mu \mathrm{m}$ longa, deorsum 10-12 $\mu \mathrm{m}$ lata, apicem versus attenuata et sursum 7.5-9 $\mu \mathrm{m}$ lata, distincte 4-9-septata, crassitunicata, laevia, modice flavidobrunnea, in coloratione uniformia, cum regenerationibus percurrentibus interdum praedita. Cellu- lae conidiogenae in conidiophoris incorporatae, polytreticae, terminales et intercalares vel interdum etiam basilares, pori ca $0.8 \mu \mathrm{m}$ diam praeditae. Conidia breve catenulata, oblonga vel ellipsoidea, utrinque late rotundata, crassitunicata, laevia, plerumque 1(-2)-septata, raro 3-septata, illa uniseptata (12-) 14-16(-17) $\times 6-9 \mu \mathrm{m}$, illa biseptata 17-22 $\times 6-9 \mu \mathrm{m}$, ad septa non constricta vel leniter constricta, modice flavidobrunnea, concoloria; septa ca $2 \mu \mathrm{m}$ crassa et atra.

Etymology. dendrocalami, referring to its habitat on Dendrocalamus.

HOLOTYPE. PHILIPPINES. LUZON, LAGUNA: Los Baños, Mt. Makiling, on senescent culms of Dendrocalamus sp., Sep. 1995, T. E. Umali E F F. Nono, TD118SP (HKU(M) 5800).

Colonies on natural substratum effuse, dark brown. Mycelium immersed. Setae and hyphopodia absent. Conidiophores arising singly or groups of 2-4, unbranched, erect, straight, attenuated, 120-280 $\mu \mathrm{m}$ long, 10$12 \mu \mathrm{m}$ wide near the base, attenuate to 7.5-9 $\mu \mathrm{m}$ wide towards the apex, distinctly 4-9-septate, thickwalled, smooth, medium yellowish brown, uniform in color, sometimes with 1-2 percurrent regenerations. Conidiogenous cells integrated, polytretic with pores ca $0.8 \mu \mathrm{m}$ diam, terminal and intercalary, sometimes also basal. Conidia borne in short chains, oblong or ellipsoidal, broadly rounded at both ends, thick- 

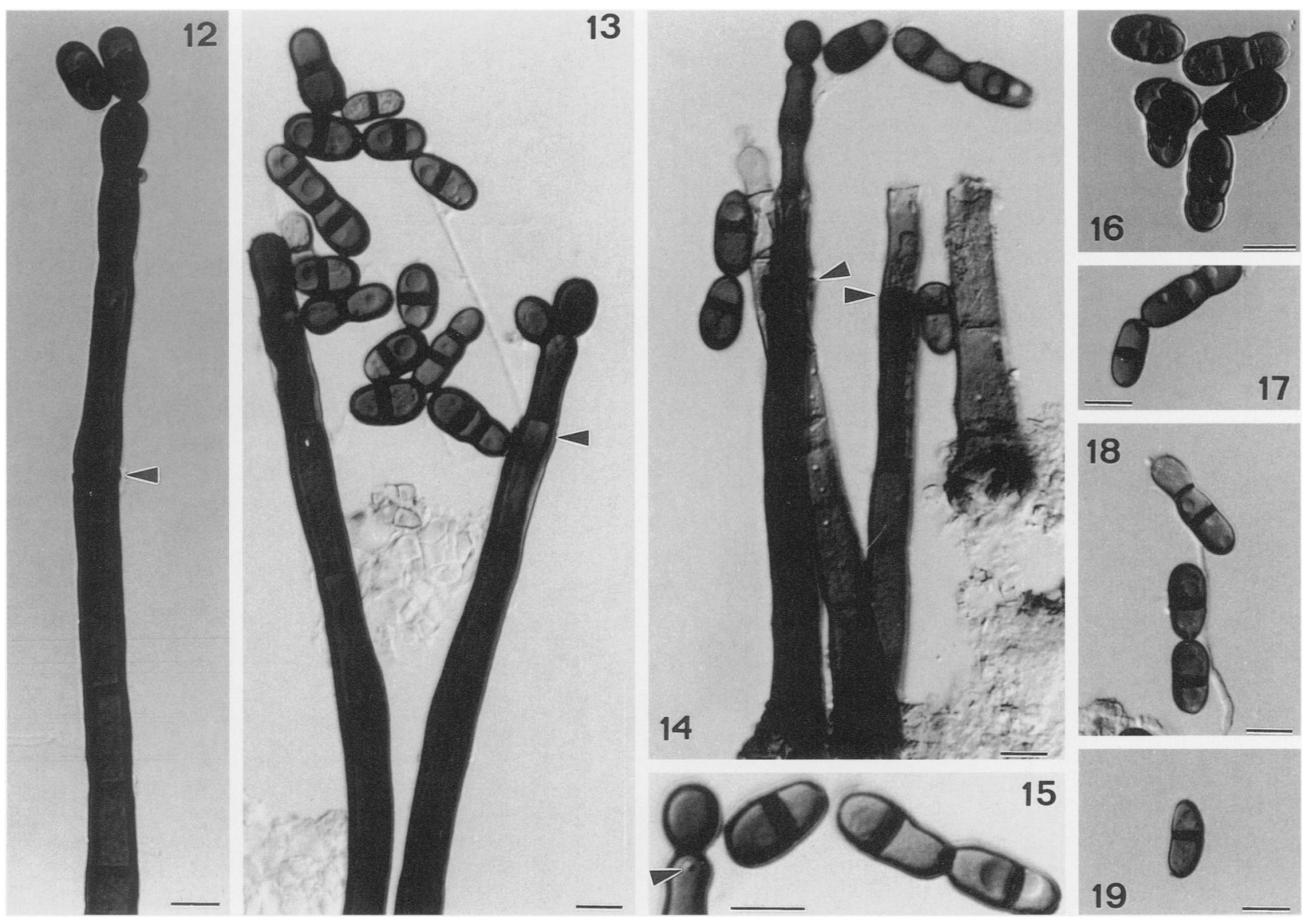

FIGS. 12-19. Diplococcium dendrocalami (from HOLOTYPE). 12-14. Conidiophores and conidia. Arrow heads show percurrent regeneration of the conidiophores. Note conidiogenous pores in 14. 15. Apex of a terminal conidiogenous cell with developing conidium and three uniseptate, mature conidia. Arrow head shows a conidiogenous pore. 16-19. Mature conidia with thick septa. Scale bars: $10 \mu \mathrm{m}$.

walled, smooth, mostly 1(-2)-septate, occasionally 3septate, not constricted or slightly constricted at the septa, medium yellowish brown, concolorous; septa ca $2 \mu \mathrm{m}$ thick and dark, usually with a visible central septal pore; uniseptate conidia (12-) 14-16(-17) $\times$ 6-9 $\mu \mathrm{m}$; 2-septate conidia 17-22 $\times 6-9 \mu \mathrm{m}$.

Teleomorph. Unknown.

Diplococcium dendrocalami somewhat resembles $D$. clavariarum (Desm.) Hol.-Jech. (Holubová-Jechová, 1982) since the conidia are approximately the same width, ellipsoidal, thick-walled, and have a thick dark septum. The latter, however, differs in having conidiophores which are chiefly branched and slender (3.5-6 $\mu \mathrm{m}$ wide). Diplococcium clavariarum has been reported as a parasite on living carpophores of $\mathrm{Cla}$ varia species (Holubová-Jechová, 1982; Samuels et al., 1997), whereas $D$. dendrocalami has been found as a saprobe. Diplococcium dendrocalami is also comparable to D. insolitum Hol.-Jech. in which the conidiophores are attenuated and sometimes regenerate percurrently (Holubová-Jechová, 1982). However, the conidia in $D$. insolitum are mainly 2-septate, tricolored, and broadly obclavate.

Acknowledgments.-We wish to thank Helen Leung, A.Y. P. Lee, and Ken M. K. Wong for their technical and photographic assistance. The University of Hong Kong is thanked for the award of a Post-doctoral Fellowship to Dr. T. K. Goh.

\section{LITERATURE CITED}

Castañeda Ruíz, R. F., and W. B. Kendrick. 1991. Ninetynine conidial fungi from Cuba and three from Canada. Univ. Waterloo Biol. Ser. 35: 1-132.

Ellis, M. B. 1963. Dematiaceous Hyphomycetes. V. Mycol. Pap. 93: 1-33.

. 1971a. Dematiaceous Hyphomycetes. X. Mycol. Pap. 125: 1-31.

. 1971b. Dematiaceous Hyphomycetes. Commonwealth Mycol. Inst., Kew, Surrey, England. 608 pp.

. 1976. More dematiaceous Hyphomycetes. Commonwealth Mycol. Inst., Kew, Surrey, England. 507 pp. 
Goh, T. K., and K. D. Hyde. 1996. Spadicoides cordanoides sp. nov., a new dematiaceous hyphomycete from submerged wood in Australia, with a taxonomic review of the genus. Mycologia 88: 1022-1031.

Holubová-Jechová, V. 1982. Lignicolous Hyphomycetes from Czechoslovakia. 6. Spadicoides and Diplococcium. Folia Geobot. Phytotax., Praha 17: 295-327.

Hughes, S. J. 1958. Revisiones hyphomycetum aliquot cum appendice de nominibus rejiciendis. Canad. J. Bot. 36: 727-836.

Matsushima, T. 1993. Matsushima mycological memoirs. No. 7. Published by the Author, Kobe. 75 pp. +131 plates.

Pirozynski, K. A. 1972. Microfungi of Tanzania. I. Miscel- laneous fungi on oil palm. II. New Hyphomycetes. Mycol. Pap. 129: 1-65.

Samuels, G. J., F. Candoussau, and J. F. Magni. 1997. Fungicolous pyrenomycetes 1 . Helminthosphaeria and the new family Helminthosphaeriaceae. Mycologia 89: 141-155.

Sinclair, R. C., A. Eicker, and D. J. Bhat. 1985. Branching in Spadicoides. Trans. Brit. Mycol. Soc. 85: 736-738.

Subramanian, C. V., and S. Sekar. 1989. Three bitunicate ascomycetes and their tretic anamorphs. Kavaka 15 (1987): 87-97.

Sutton, B. C. 1973. Hyphomycetes from Manitoba and Saskatchewan, Canada. Mycol. Pap. 132: 1-143.

Wang, C. J. K., and B. C. Sutton. 1982. New and rare lignicolous Hyphomycetes. Mycologia 74: 489-500. 